Saint-Petersburg State University of Culture,

\title{
O.S. Kovalchuk
}

National University of Food Technologies, Kiev, Ukraine

\section{ELECTRONIC MUTILINGUAL TERMINOLOGICAL DICTIONARY (EMTD) FOR BUSINESS AND PROFESSIONAL FOREIGN LANGUAGE TEACHING AND LEARNING}

The study has direct implications for the successful implementation of computer assisted language learning (CALL) and effective use of electronic dictionaries in English, German, Russian FL teaching and learning contexts. EMTD is presented as the product of the National University of Food Technologies. It attracts students of tertiary education as less time is needed to look up the meaning of a word in such a dictionary. It also helps teachers to give good lessons, work with educational material, explain word meanings, and achieve academic objectives. The EMTD not only defines terms but also provides English, German, Ukrainian and Russian equivalents, word combination, and contributes to the description of the terminology. Today with a big variety of electronic dictionaries in terms of forms and function users look for such features of an electronic dictionary as: type/number of dictionaries; translation capability; thesaurus; pronunciation; stylus; data transport; learning programs; encyclopedia; built-in camera; added features the demand for them is not quite big. However in higher schools such dictionaries can be of value. NUFT have chosen the features that take best advantage of the medium. The survey is designed for the purposes to find the ways how to improve user-friendly features of EMTD (combination of $A / Z$ and subject search) and evaluate it. The sample evaluation programme carried out by two groups, a group of teachers and a group of computer experts, gives positive results. Thanks to the EMTD students extend their Business and Professional vocabularies and what is quite important for teaching and learning processes virtually improve language (reading) skills.

Keywords: CALL, electronic multilingual terminological dictionary, foreign languages teaching and learning, Business English, tertiary education, multimedia. 
Л.А. Девель

Санкт-Петербургский институт культуры, Санкт-Петербург, Россия
Получено: 10.11.2016

Принято: 18.11 .2016

Опубликовано: 30.12.2016

\title{
О.С. Ковальчук
}

Национальный университет пищевых технологий, Киев, Украина

\section{ЭЛЕКТРОННЫЙ МНОГОЯЗЫЧНЫЙ ТЕРМИНОЛОГИЧЕСКИЙ СЛОВАРЬ (ЭМТС) ДЛЯ ОБУЧЕНИЯ ДЕЛОВОМУ И ПРОФЕССИОНАЛЬНОМУ ИНОСТРАННОМУ ЯЗЫКУ}

\begin{abstract}
Настоящее исследование имеет непосредственное значение для практики компьютерной лингводидактики и эффективного использования многоязычных англо-русско-немецко-украинских словарей в обучении. ЭМТС разработан в Национальном университете пищевых технологий (НУПТ). Он нравится студентам, так как в нем, чтобы найти значение слова, требуется меньше времени. Словарь также помогает преподавателям сделать занятия качественнее, успешнее работать с учебным материалом, объяснять значения слов и достигать поставленных академических целей и задач. ЭМТС дает определения терминов и их объяснения, эквиваленты слов на английском, русском, немецком и украинском языках, словосочетания. Сегодня при большом разнообразии выбора электронных словарей пользователи предпочитают такие характеристики, как: типы/количество включенных словарей, качество перевода, тезаурус, произношение, стиль, перенос данных, учебные программы, энциклопедия, встроенная камера, другие характеристики. Спрос на них невысок. Тем не менее в высшей школе подобные словари могут находить применение. НУПТ выбрал наиболее выигрышные характеристики. Проведенное опрос-исследование предназначено определить, как улучшить пользовательские характеристики (сочетание алфавитного и предметного поиска) и оценить ЭМТС. Программа по оцениванию, выполненная двумя группами респондентов - группой преподавателей и группой экспертов компьютерщиков, - показала положительные результаты. Благодаря ЭМТС студенты расширяют профессиональный и бизнес-вокабуляр и, что особенно важно для процесса обучения, значительно совершенствуют языковые навыки (чтения).

Ключевые слова: компьютерная лингводидактика, электронный многоязычный терминологический словарь, обучение, иностранные языки, деловой английский, высшее образование, мультимедиа.
\end{abstract}

Introduction. The language teaching at the National University of Food Technologies (NUFT), Ukraine is characterised by studying business, economic and technical literature containing many terms. Our practice shows, that traditional lexicography cannot meet the increasing demand in terminological dictionaries of the given field. As we know, computerization of compiling dictionaries significantly reduces time-frames and helps the search for a specific material. Besides, automated links simplifies the problem of overloading the dictionary and time spent on it. The EMTD not only defines terms but also provides English, German, Ukrainian and Russian equivalents, word combination, and contributes to the description of the terminology $[1 ; 2]$.

Under the «electronic» dictionary one can understand any reference material in electronic form giving information about the spelling, meaning, or use of words. Thus a spell-checker in a word-processing program, a device that scans and translates printed words, a glossary for on-line teaching materials, or an electronic version of a respected hard-copy dictionary are all electronic dictionaries characterized by the 
same system of storage and retrieval [3: 839]. Students rather appeal to the experience of using the retrieval system, than to the information content. Hard-copy dictionaries organize information in a primarily linear way, which is appropriate for the listing of a succession of separate entries, but inadequate as a means of grouping and regrouping words according to their semantic and pragmatic similarities, their valency and collocational patterning, or simply their letter combinations.

Today there is a big variety of electronic dictionaries in terms of forms and function $[4 ; 5 ; 6 ; 7 ; 8 ; 9 ; 10 ; 11]$. There are five main types of Electronic Dictionaries: a standalone, handheld electronic device, CD-ROMs and DVD-ROMs, conventional, printed dictionary. These programs can then be loaded onto personal computers, free or pay-for-use online dictionaries. Besides the more recent forms of technology, such as eReaders, tablet computers, and smartphones, now have electronic dictionary capabilities. One can look for such features of an electronic dictionary as:

1) type/number of dictionaries;

2) translation capability;

3) thesaurus;

4) pronunciation;

5) stylus;

6) data transport;

7) learning programs;

8) encyclopedia;

9) built-in camera;

10) added features.

Available in a number of forms and types, electronic dictionaries range in function from general single-language dictionaries to multi-language and to very specific, terminology-based dictionaries for medical, legal, and other professional languages. The list of professional languages can be quite big. Today the demand for electronic dictionaries is not quite big. However in higher schools such dictionaries can be of value.

NUFT lexicographers have chosen the features that take the best advantage of the medium, and have produced the lexicographical material for the Internet and CD-ROM, without any hardcopy version. EMTD implements some modern search manners: one click from an entry like in the Longman Web Dictionary and straight to all «related entries» or like in Collins E-dictionary which offers easily activated searches through words with similar grammatical behavior $[12 ; 13]$. A special survey is carried out.

Objectives. The survey puts such questions:

1. What electronic dictionary is user-friendly?

2. Does the e-dictionary suit the user well?

3. Is the EMTD reliable and easy to use? 
The survey is designed for the purposes to find the ways how to improve user-friendly features of EMTD (combination of A/Z and subject search) and evaluate it. Reading skill refers to the ability to spell or translate a symbol or a letter, as well as the ability to understand the overall content of the reading material. This understanding depends on the knowledges of a student his or her vocabularies.

Methods. Assuming the principle that a good definition should1facilitate understanding of a term and distinguish the given and related terms, the following rules have been agreed upon:

1. a definition must contain or lead to no logical contradictions;

2. the term to be defined must not appear either openly or implicitly;

3. a definition should have positive predicate;

4. a term should be neither overdefined nor underdefined;

5. a definition of the term is to be defined in the simplest possible language;

6. a definition is to be clear and concise.

To achieve accuracy the EMTD was verified by using a large-scale computer textbase.

Dictionary users are supposed to develop properly two primary dictionary skills: to choose the necessary dictionary and to know how to use it [4]. The advent of electronic dictionaries has placed much greater demands on dictionary users in this respect. Different dictionary formats suit different language activities, so now the choice is not just between a learners' dictionary or a native speakers' dictionary, general or specialist, bi- or monolingual, but also between a dictionary that requires access to a networked computer, a dictionary with links to a wordprocessing program, or a portable dictionary to consult while speaking and listening, or while reading hardcopy text. Nevertheless it is not hard to find comparative information about hardcopy dictionaries, as they are well known to teachers, reviewed in teaching journals, and available for inspection in bookshops and libraries. In contrast there are very few sources of unbiased advice available to the language learner who needs to select the right electronic dictionary for the job. One difficulty with dictionary skills is settled as electronic dictionaries are mostly userfriendly. But to choose a proper dictionary is no easy issue. The most fundamental dictionary skill of a dictionary user - selecting an appropriate dictionary for a given task is a special subject to be described and discussed separately.

According to the Oxford English Dictionary dictionaries designed for the use of foreign students are usually called Learner's Dictionaries [3, p. 187]. They are characterised by developing new ways of defining words and providing necessary information for encoding. It is the latter feature that explains most of their characteristics as given below:

1. The language described is the usual everyday variety, not the formal or literary;

2. Preference is given to the quality of the treatment of words rather than to the quantity of words; 
3. Particular care is taken in the treatment of the most frequent words;

4. The obligatory or preferred syntactic patterns of verbs (at least) and nouns and adjectives, countable or uncountable nouns, irregular forms of plurals, comparatives, conjugations, etc., are all indicated;

5. Pronunciation is written in IPA;

6. Many examples are given, always representative of normal, everyday usage.

Research Design. The development of the EMTD is a 4 step process which includes:

1. Data collection and input.

2. Database. Software identification.

3. Evaluation. The program needs to be evaluated from the standpoint of its accuracy and suitability.

4. Improvement. The improvement is carried out on the basis of the 7 evaluator's proposal.

Regarding data collection and input, software identification we talk about creating the EMTD database.

The sample evaluation programme is carried out by two groups. The first group of 3 experienced teachers of English and German pay attention to the EMTD suitability and applicability to the curriculum. The second group of 3 computer database and programming experts check the Java suitability and the user-friendly features.

Results. EMTD offers users:

- Quick search / full view; Search techniques are ways to find a word meaning quickly. By introducing a query, an expression in a resource, the user obtains a result (the meaning of a word, usage context, etc.) [14, p. 104].

- Languages search available (Russian-English-Ukrainian-German) The four-language search is made by introducing a word in any of the given languages in the dictionary. Such search is used in EMTD to find an entry giving information about the introduced word;

- A/Z search;

- subject search: general terms, evaluation, output, cost-accounting output, accountancy, bookkeeping, types of balance sheets, liquidity, financing, investment. The dictionary entries are classified into thematic areas [14, p.126]. A subjectltopicltheme search index is a list of hierarchically ordered areas, with the help of which the user can navigate and select the item she or he wants to check.

The EMTD is the offline dictionary as it is considered to be more reliable in comparison with online dictionaries. Online dictionaries may change their URL location any time, or disappear. The EMTD has the format of a compact disc. The offline dictionary can be used on a computer or a personal data assistant (PDA). The advantage of this type of a dictionary is that users are not dependent on Internet availability. According to the RF resources the comparison of the most popular offline/online dictionaries used can confirm that that feature has been quite important for users [5, p. 40-57]. 
The NUFT Department for Business Foreign Languages and International Communication think that the dictionary is applicable within the framework of the University the curriculum because of its following characteristics:

- accuracy;

- well arranged system of information $\backslash$ data;

- complete data;

- appropriate language wording;

- up-to-date educational standards;

- multi aspect educational value;

- encouragement of students' interest $\backslash$ motivation to use the dictionary:

- help to improve students' reading skills.

The specialty terms usage was checked.

Discussion. The EMTD testing shows that: interactivity and controllability are high; menu, search and control methods are simple and easy to use. It has easyto-read and appropriate font, consistent screen layout; it has no technical errors. High reliability has been pointed out by the computer experts: no failures, it saves time; technology is good; the look is user-friendly.

Suggestions for further improvement. To enlarge the dictionary towards different subject areas of economics and technology, to provide audio elements, to create more attractive layout and introduce colour print and pictures [15].

Summing up. Electronic dictionaries formats have become more attractive with time. According to our survey, students extend their Business and Professional vocabularies thanks to the EMTD. What is quite important for teaching and learning processes the dictionary help students virtually improve language (reading) skills. Here there is a special description of students' or teachers' perspectives on the use of electronic dictionaries in English, German, Russian as foreign languages classroom, when in general only limited research has been undertaken identifying both EFL teachers' and students' perspectives on the use of electronic dictionaries for learning English. So the described survey can contribute to this area of computer assisted language learning - CALL research. The given case can certify that implementing electronic dictionaries are useful in a higher school classroom environment, which agrees with the practice described by many EFL teachers, for example from the People's Republic of China, Islamic Republic of Iran, Japan [16, 17].

\section{References}

1. Elektronnii ukraïns'ko-rosiis'ko-angliis'ko-nimets'kii tlumachnii slovnik dlia studentiv ekonomichnikh fakul'tetiv [Online Ukrainian-Russian-English-German explanatory dictionary for students in economics]. Naukovo-tekhnichna b-ka Nats. un-ta kharchovikh tekhnologii. Kiev, 2012-2014. Available at: http://library.nuft.edu.ua/ebook/ datathree.php?ID=507 (accessed 25 Oct. 2016). 
2. Kovalchuk O.S. The Development and Use of Electronic Multilingual Terminological Dictionary. Available at: http://dspace.nuft.edu.ua/jspui/bitstream/123456789/ 15654/1/5.pdf (accessed 25 Oct. 2016).

3. Oxford English Dictionary. Additions Series. Vol. 3. Ed. by Michael Proffitt. Oxford, Oxford University Press, 1997.

4. Devel' L.A. Vvedenie v leksikografiiu: vybor slovarei [Introduction to lexicography: Selection of the dictionaries]. Saint-Petersburg, Pechatnyi dom Publ., 2005.

5. Devel' L.A. Anglo-russkii uchebnyi slovar'. Lingvodidakticheskie problemy ispol'zovaniia $\mathrm{v}$ informatsionnom poiske $\mathrm{i}$ distantsionnom obuchenii $\mathrm{v}$ nepreryvnom obrazovanii [English-Russian learner's dictionary. Linguodidactic issues of its use in information search and distance learning in continuous education]. Saint-Petersburg, Kul'tInform-Press Publ., 2011.

6. Nesi H. [et al.]. Electronic Dictionaries in Second Language Vocabulary. Comprehension and Acquisition: the State of the Art. Proceedings of the Ninth EURALEX International Congress (Stuttgart, Germany, August 8th-12th, 2000), vol. II. Stutgart, 2000, pp. 839-847.

7. Ceccarelli M. Technology Developments: The Role of Mechanism and Machine Science and IFToMM. Vol. 1, 2011, pp. 95-105.

8. Pastor V., Alcina A. Search Techniques in Electronic Dictionaries: A Classification for Translators. International Journal of Lexicography, 2010, no. 23 (3), pp. 307-354.

9. Dictionaries. An International Encyclopedia of Lexicography. Supplementary Volume: Recent Developments with Focus on Electronic and Computational Lexicography. Berlin, De Gruiter, 2013.

10. Domínguez V., José M., Kutscher S. Interacción entre gramática, didáctica y lexico-grafía. Berlin, De Gruiter, 2016.

11. Klosa A., Müller-Spitzer C. Internetlexicographie. Berlin, De Gruiter, 2016.

12. Adamska-Sałaciak A., Kernerman I. Introduction: Towards Better Dictionaries for Learners. International Journal of Lexicography, 2016, no. 29 (3), pp. 271-278.

13. Halpern J. Compilation Techniques for Pedagogically Effective Bilingual Learners' Dictionaries. International Journal of Lexicography, 2016, no. 29 (3), pp. 323-338.

14. The Bloomsbury Companion to Lexicography. Ed. by H. Jackson. London, Bloomsbury Academic, 2013. XIII, 420 p.

15. Atkins S., Rundell M. The Oxford Guide to Practical Lexicography. Oxford, Oxford University Press, 2008.

16. Zheng H., Wang X. The Use of Electronic Dictionaries in EFL Classroom. Studies in English Language Teaching, vol. 4, no. 1, 2016. Available at: www.scholink.org/ojs/index.php/selthttp (accessed 01 Jan. 2016).

17. Dashtestani R. EFL teachers' and students' perspectives on the use of electronic dictionaries for learning English. CALL-EJ, no. 14 (2), pp. 51-65. Available at: http://callej.org/journal/14-2/Dashtestani_2013.pdf (accessed 01 Jan. 2016). 


\section{Список литературы}

1. Електронний українсько-російсько-англійсько-німецький тлумачний словник для студентів економічних факультетів [Электронный ресурс] // Науковотехнічна б-ка Нац. ун-та харчових технологій [сайт]. - Киев, 2012-2014. - URL: http://library.nuft.edu.ua/ebook/ datathree.php?ID=507 (дата обращения: 25.10.2016).

2. Kovalchuk O.S. The Development and Use of Electronic Multilingual Terminological Dictionary [Электронный pecypc]. - URL: http://dspace.nuft.edu.ua/jspui/ bitstream/123456789/15654/1/5.pdf (дата обращения: 25. 10.16).

3. Oxford English Dictionary Additions Series: Vol. 3 / Ed. Michael Proffitt. - Oxford: Oxford University Press, 1997.

4. Девель Л.А. Введение в лексикографию: выбор словарей: учеб. пособие для самостоятельной работы, материалы семинара. - СПб.: Печатный дом, 2005.

5. Девель Л.А. Англо-русский учебный словарь. Лингводидактические проблемы использования в информационном поиске и дистанционном обучении в непрерывном образовании: монография. - СПб.: КультИнформПресс, 2011.

6. Electronic Dictionaries in Second Language Vocabulary. Comprehension and Acquisition: the State of the Art / H. Nesi [et al.] // EURALEX 2000: Proceedings of the Ninth EURALEX International Congress, Stuttgart, Germany; August 8th-12th, 2000. Stutgart: Euralex, 2000. - Vol. II. - P. 839-847.

7. Ceccarelli M. 2011.Technology Developments: The Role of Mechanism and Machine Science and IFToMM. - 2011. - Vol. 1. - P. 95-105.

8. Pastor V., Alcina A. Search Techniques in Electronic Dictionaries: A Classification for Translators // International Journal of Lexicography. - 2010. - 23 (3). - P. 307-354.

9. Dictionaries. An International Encyclopedia of Lexicography. Supplementary Volume: Recent Developments with Focus on Electronic and Computational Lexicography. Berlin: De Gruiter, 2013.

10. Domínguez V., José M., Kutscher S. Interacción entre gramática, didáctica y lexicografía. - Berlin: De Gruiter, 2016.

11. Klosa A., Müller-Spitzer C. Internetlexicographie. - Berlin: De Gruiter, 2016.

12. Adamska-Sałaciak A., Kernerman I. Introduction: Towards Better Dictionaries for Learners // International Journal of Lexicography. - 2016. - 29 (3). - P. 271-278.

13. Halpern J. Compilation Techniques for Pedagogically Effective Bilingual Learners' Dictionaries // International Journal of Lexicography. - 2016. - 29 (3). - P. 323-338.

14. The Bloomsbury Companion to Lexicography / ed. H. Jackson. - London: Bloomsbury Academic, 2013. - XIII. - 420 p.

15. Atkins S., Rundell M. The Oxford Guide to Practical Lexicography. - Oxford: Oxford University Press, 2008.

16. Zheng H., Wang X. The Use of Electronic Dictionaries in EFL Classroom [Электронный ресурс] // Studies in English Language Teaching. - 2016. - Vol. 4, No. 1. URL: www.scholink.org/ojs/index.php/selthttp (дата обращения: 1.1.2016).

17. Dashtestani R. EFL teachers' and students' perspectives on the use of electronic dictionaries for learning English [Электронный ресурc] // CALL-EJ. - 14(2). - P. 51-65. URL: http://callej.org/journal/14-2/Dashtestani_2013.pdf (дата обращения: 1.1.2016). 


\section{Сведения об авторах}

\section{ДЕВЕЛЬ Людмила Александровна}

e-mail: miladevel@gmail.com

Кандидат филологических наук, доцент кафедры иностранных языков и лингвистики, Санкт-Петербургский институт культуры (Санкт-Петербург, Россия)

\section{КОВАЛЬЧУК Ольга Сергеевна}

e-mail:kovalchuk@online.ua

Старший преподаватель кафедры делового иностранного языка и международной коммуникации, Национальный университет пищевых технологий (Киев, Украина)

\begin{abstract}
About the authors
Liudmila A. DEVEL

e-mail:miladevel@gmail.com

Candidate of Philological Sciences, Associate Professor, Department of Foreign Languages and Linguistics, Saint-Petersburg State University of Culture (Saint-Petersburg, Russia)

\section{Olga S. KOVALCHUK}

e-mail:kovalchuk@online.ua

Assistant Professor, Department of Business Foreign Languages and International Communication, National University of Food Technologies (Kiev, Ukraine)
\end{abstract}

